\title{
Comparative effects of organic compost and NPK fertilizer on soil fertility, yield and quality of amaranth in southwest Nigeria
}

\author{
F.O. ADEKAYODE ${ }^{1^{*}}$ and M.O. OGUNKOYA ${ }^{2}$ \\ ${ }^{l}$ Department of Crop, Soil and Pest Management, Federal University of Technology, Akure, Nigeria. \\ ${ }^{2}$ Federal College of Agriculture, Akure, Nigeria. \\ *Corresponding author, E-mail: adekay98@yahoo.com
}

\begin{abstract}
The need for an increased production of vegetables to meet the dietary vitamin requirements of the people had necessitated a research in the use of manure in improving the soil fertility for an improved yield and quality of amaranth. The research was conducted in Obasoto Farm (latitude $7^{\circ} 10^{\prime} \mathrm{N}$ and longitude $5^{\circ} 37^{\prime} \mathrm{E}$ ) in Owo Local Government Area of Ondo State, Nigeria in the early and late seasons of 2007, 2008 and 2009. The experimental design was a randomized complete block with three treatments replicated three times. The three treatments were $0 \mathrm{~kg} / \mathrm{ha}$ manure, 2t/ha organic compost and $200 \mathrm{~kg} / \mathrm{ha}$ NPK 15-15-15. Amaranthus cruentus seeds obtained from the Ondo State Agricultural Development Project were raised in the nursery and transplanted at a spacing of $10 \times 20 \mathrm{~cm}$ into $1 \times 3$ meter manually prepared beds. Each manure type was incorporated by ploughing it in while preparing the bed at $600 \mathrm{~g}$ organic compost and $60 \mathrm{~g}$ NPK 15-15-15 fertilizer per the $1 \times 3$ meter bed respectively. Pre-treatment and post planting soil samples were taken for laboratory soil analysis of soil chemical properties for a comparison of the assessment of the cumulative effects of organic compost and inorganic fertilizer in improving soil fertility over a period of three years. The organic matter increased by $23.3 \%$ and $0.6 \%$ in the second and third year respectively in the plot treated with organic compost, while there was no such increase trend in the plot treated with $200 \mathrm{~kg} \mathrm{NPK} / \mathrm{ha}$. The organic matter content correlated positively with the yield and vitamin C content of amaranth.
\end{abstract}

(C) 2011 International Formulae Group. All rights reserved.

Keywords: Organic compost, NPK fertilizer, soil fertility improvement, yield and quality of amaranth.

\section{INTRODUCTION}

The nutritive values of amaranth and other vegetables in the diet of people had been discussed in previous research (BodrozaSolarov et al., 2008). The consumption of vegetables in diet had been reported to protect the human body from degenerative diseases as the main protective action of vegetables had been attributed to the antioxidants present in them (Ogunlesi et al., 2010).
In the study carried out to determine the nutritional quality of the protein of amaranth grain, Bressani et al. (1993) concluded that the amaranth protein was among the highest in nutritive quality of vegetable origin and close to those of animal origin products. Akingbade et al. (1994) in the evaluation of amaranth grain for its ogi making quality with the amylograph pasting viscosity analysis, reported amaranth ogi to have slightly higher peak viscosity and lower 
set back value than corn ogi and from the study, concluded that amaranth grains would be suitable for ogi manufacture. The high vitamin $\mathrm{C}$ content of amaranth had also been reported (Condes et al., 2009; Tironi and Anon, 2010).

The cooked leaves of amaranth are eaten in different ways according to local custom either as a vegetable soup or sauce though it is recommended that the leaves should not be boiled for more than fifteen minutes, in order to prevent significant losses of the vitamin $\mathrm{C}$ in them. The previous discussion by De-Lannoy (2001) on the composition of amaranth indicated one hundred grams to contain 3.6 to $4.6 \mathrm{~g}$ protein, 154 to $410 \mathrm{mg}$ calcium, 2.9 to $8.9 \mathrm{mg}$ iron, 5.7 to $6.5 \mathrm{mg}$ beta-carotene, 23 to $64 \mathrm{mg}$ vitamin $\mathrm{C}$ respectively.

The improved performance, yield and quality of amaranth as a result of application of inorganic fertilizer and organic manure to soils had been reported in previous research (Ali et al., 2009). The use of manure to improve soil fertility can be categorized into inorganic, organic and a mixture of inorganic and organic manure types. The use of inorganic fertilizer in improving soil fertility had been discussed to have direct and fast effects as nutrients in fertilizers are soluble and immediately available to plants and only relatively small amounts would be required for the crop growth since they are quite high in nutrient content (Makinde et al., 2010). Organic fertilizer on the other hand, had more balanced nutrient supply, create better soil structure thereby enhancing root growth while the slow release of the nutrients would contribute to the residual pool of organic nitrogen and phosphorus in the soil though organic fertilizer being low in nutrient content would make larger quantity to be needed to provide enough nutrients for crop growth and the long term or heavy application may result in salt and heavy metal accumulation which may adversely affect plant growth (Ramesh et al., 2009).
The effects of long term use of either organic manure or inorganic fertilizer on soil properties and the performance of vegetables and other arables had also been discussed (Ali et al., 2009). An increase in soil organic matter had been reported to cause an increase in soil microbial population (Chitravadivu et al., 2009; Nakhro and Dkhan, 2010) while Selma et al. (2010) reported increase in microbial population to result in increased antioxidant capability of soil which view had earlier been reported in the research findings of Skwarylo-Bednarz and Krzepilko (2009) of high soil antioxidant capability resulting in high antioxidant in amaranth.

The overuse of inorganic fertilizers could cause detrimental effects on soil productivity as observed by Mae-Wan Ho (2010) who reported crop land soils in China turning acid from the overuse of nitrogen fertilizers for which he recommended a reduction in the use of inorganic fertilizers while Devaney (2010) reported that some of the chemical fertilizers used contained sulfuric acid and hydrochloric acid.

The previous research on comparative study of inorganic and organic manure effects on soils properties and production of amaranth had mostly been the use of poultry manure, goat manure, green manure or farmyard manure alone whereas there was the need to investigate more intensely the study with composted biodegradable integrated with organic manure that could be bagged and packaged for easy handling and application by vegetable farmers. The objective of this research was to study the effects of application of NPK fertilizer and organic compost on soil properties and production of amaranth for three consecutive years of 2007, 2008 and 2009, and to also investigate the effect of the manure on vitamin $\mathrm{C}$ content of amaranth.

\section{MATERIALS AND METHODS Site description}

The experiment was carried out at the Obasoto Farm in Owo in Ondo State, Nigeria, 
in the early season (May to June) and late season (September to October) of 2007, 2008 and 2009. The experimental site was located on (latitude $7^{\circ} 10^{\prime} \mathrm{N}$ and longitude $5^{\circ} 37^{\prime} \mathrm{E}$ ) within the forest-savannah transition zone of southwest Nigeria with a semi-deciduous vegetation. Soil at Owo was an Alfisol derived from medium grained granite, schist and gneiss (Smyth and Montgomery, 1962). The rainfall pattern was bimodal with a definite cycle of rainy season of March to October and dry season of November to February. The experimental site had been cropped continuously for arable maize production for three years without fertilizer application and had been left fallow for three years before commencement of the experiment. The predominant weeds were siam weed (Chromolaena odorata) and guinea grass (Aspilia africana).

\section{Preparation of organic composts}

The organic compost was prepared by composting organic materials using basket method of composting (Madeleine et al. 2002). The circular outline of a $60 \mathrm{~cm}$ diameter and $60 \mathrm{~cm}$ deep pit was lined with a basket. The bottom was filled to a thickness of $10 \mathrm{~cm}$ with crop residues (maize stalks and shelled cobs) of the previous harvest. Cured poultry manure was added to a thickness of 15 $\mathrm{cm}$ while green young leaves and wood ash were added to a thickness of $15 \mathrm{~cm}$ and 0.5 $\mathrm{cm}$ respectively. Repeatedly, cured poultry manure, green young leaves and wood ash were added in layers until the pit was full. The top of the pit was covered with banana leaves. After three weeks, the pile was turned to a second pit and after another three weeks, turned into the third pit and left to mature at the tenth week before application to the crops in the field. A shed was made over the compost pits.

\section{Chemical analysis of the organic compost}

$2 \mathrm{~g}$ of the processed forms of the organic compost was analyzed. The nitrogen content was determined by micro-Kjeldahl method. The organic carbon was determined by wet oxidation method through chromic acid digestion while $\mathrm{P}, \mathrm{K}, \mathrm{Ca}, \mathrm{Mg}, \mathrm{Fe}, \mathrm{Zn}, \mathrm{Cu}$ and $\mathrm{Mn}$ were determined using the perchloric acid digestion (wet oxidation) method (AOAC, 1970).

\section{Soil sampling and analysis before planting}

Prior to the commencement of the experiment in 2007, fifteen core $(4 \mathrm{~cm}$ diameter, $10 \mathrm{~cm}$ high) soil samples were collected randomly from 0 to $15 \mathrm{~cm}$ depth in the site using soil auger, thoroughly mixed and the bulk sample taken to the laboratory, air dried and sieved to pass through a $2 \mathrm{~mm}$ screen for soil physical and chemical analysis.

\section{Field experiments and manure treatment}

Amaranth seeds obtained from the Ondo State Agricultural Development Project were mixed with dry sand and sown by broadcasting in the nursery made of $1 \times 1$ meter wooden tray filled with soil from the experimental site and the seedlings later transplanted at 2 weeks at a spacing of $10 \mathrm{~cm}$ x $20 \mathrm{~cm}$ on $1 \mathrm{~m} \mathrm{x} 3 \mathrm{~m}$ beds to give a population of 150 plants per bed. Three beds were contained in each treatment plot. The experimental design was a randomized complete block with three treatments replicated three times. The three treatments were $0 \mathrm{~kg} / \mathrm{ha}$ manure, $200 \mathrm{~kg} / \mathrm{ha}$ NPK 15-1515 and 2 t/ha organic compost. Each manure type was incorporated by ploughing it in while preparing the bed at $600 \mathrm{~g}$ organic compost and $60 \mathrm{~g}$ NPK 15-15-15 fertilizer per the $1 \times 3$ meter bed respectively.

\section{Post planting soil sampling and analysis}

A core $(4 \mathrm{~cm}$ diameter, $10 \mathrm{~cm}$ high) soil samples in a $60 \mathrm{~cm} \times 60 \mathrm{~cm}$ quadrat in each bed was taken at harvest for soil chemical analysis. The soil samples in each treatment plot were bulked, air-dried and sieved through a $2 \mathrm{~mm}$ sieve and analysed following the laboratory procedures described 
by Carter (1993). The soil pH was determined in water using a glass electrode $\mathrm{pH}$ meter. Organic carbon was determined by oxidising soil sample with dichromate solution and later titrated with ferrous sulphate solution. The total nitrogen was determined using microKjeldahl method and the available phosphorus determined by the Bray P-1 method. The exchangeable cations were extracted by leaching $5 \mathrm{~g}$ of soil with $50 \mathrm{ml}$ ammonium acetate at $\mathrm{pH}$ 7. The potassium and sodium in the leachate were determined with a flame spectrophotometer while the calcium and magnesium were determined with atomic absorption spectrophotometer. The exchangeable acidity was determined by adding barium chloride buffer solution to soil sample and titrated against $0.1 \mathrm{~N} \mathrm{HCl}$.

\section{Agronomic parameters and data collection}

Eighteen plants within the $60 \mathrm{~cm} \times 60$ $\mathrm{cm}$ quadrat located for soil sampling in each bed were harvested for the yield for statistical analysis.

\section{Determination of the vitamin $C$ content of Amaranthus}

The vitamin $\mathrm{C}$ content was determined by titration with $\mathrm{N}$-bromosuccinimide as described in Ogunlesi et al. (2010) and the values obtained in $\mathrm{mg} / 100 \mathrm{~g}$ of sample.

\section{Statistical analysis}

Data were collected in 2007, 2008, 2009 and subjected to analysis of variance (ANOVA) test with the treatment means compared using the Least Significant Difference (LSD) at $5 \%$ probability.

\section{RESULTS}

\section{Pre-treatment soil analysis}

Table 1 shows the result of the pretreatment soil analysis. The soils were sandy, loam and slightly acidic. The organic matter, total nitrogen, available phosphorus and exchangeable potassium, calcium and magnesium were low.

\section{Chemical analysis of the organic compost}

Table 2 shows the chemical analysis of the organic compost used for the experiment. The compost, in addition to having high NPK content, also contained sufficient quantities of calcium and magnesium with the micro nutrient elements of iron, cupper and zinc, while the $\mathrm{C} / \mathrm{N}$ ratio of 6.46 indicated medium to high nitrogen content.

\section{Soil chemical properties at harvest}

Tables 3, 4 and 5 show the soil chemical properties at harvest for 2007, 2008 and 2009. The soil $\mathrm{pH}$ did not show any significant differences in 2007 and 2008 but in 2009 , there were significant differences in the inorganic fertilizer and the organic compost plots with significantly higher value in the organic compost plot and a significantly lower $\mathrm{pH}$ value depicting higher acidity in the NPK plot. The organic matter content was significantly higher in the plot treated with organic compost compared to the other treatment plots. The observed high organic matter in the organic compost plot was followed by the organic matter content in NPK and the control $(0 \mathrm{~kg} / \mathrm{ha})$ in a decreasing order of magnitude. An increase in organic matter was observed in 2008 over 2007 and in 2009 over 2008 in the organic compost treated plot whereas no such significant increases were observed in the NPK treated plot. There was however higher nitrogen, phosphorus, potassium and cation exchange capacity in plot treated with $200 \mathrm{~kg}$ NPK fertilizer over the organic compost manure in the first year 2007, while in second year 2008 and the third year 2009, significantly higher nitrogen, phosphorus, potassium and cation exchange capacity were observed in the plot treated with organic compost compared to the plot treated with NPK fertilizer. 
Effects of organic compost and inorganic NPK fertilizer on the yield and vitamin C content of amaranth

Table 6 shows the effects of organic compost and NPK fertilizer on the yield and vitamin C content of amaranth in 2007, 2008 and 2009. There was observed significant increase in the yield and vitamin $\mathrm{C}$ content of amaranth in NPK treated plot compared to the other plots in 2007, while in 2008 and 2009, there were significantly higher values in the yield and vitamin $\mathrm{C}$ content of amaranth in the compost treated plot compared to NPK and control plot without manure respectively. The yield and vitamin $\mathrm{C}$ content of amaranth correlated with the soil organic matter content. The correlation between organic matter and yield were $0.28,0.85$ and 0.84 in 2007, 2008 and 2009 respectively while the correlation between organic matter and the vitamin $\mathrm{C}$ were $0.25,0.69$ and 0.67 respectively in 2007 , 2008 and 2009.

\section{The yearly changes in soil chemical properties, yield and vitamin $\mathrm{C}$ content of amaranth}

The long-term cumulative effect of organic matter obtained from the addition of organic compost was observed in Table 7 which showed the yearly increase of organic matter in plot treated with organic compost. This had a correspondingly increasing content of nitrogen, phosphorus, potassium, calcium, magnesium, cation exchange capacity, yield and the vitamin $\mathrm{C}$ content. There was no such increase trend in plot treated with NPK fertilizers in Table 8 .

Table 1: Physical and chemical properties of soils $(0-15 \mathrm{~cm}$ depth) in the experimental site in 2007 before the commencement of the experiment.

\begin{tabular}{ll}
\hline Soil property & Value \\
\hline Sand $(\%)$ & 67 \\
Silt $(\%)$ & 12 \\
Clay $(\%)$ & 21 \\
Soil texture & Sandy loam \\
pH $\left(\mathbf{H}_{\mathbf{2}} \mathbf{O}\right)$ & 6.3 \\
Organic matter $(\mathbf{g} / \mathbf{k g})$ & 2.17 \\
Total $\mathbf{N}(\mathbf{g} / \mathbf{k g})$ & 0.13 \\
Available $\mathbf{P}(\mathbf{m g} / \mathbf{k g})$ & 6.2 \\
Exchangeable $\mathbf{K}(\mathbf{c m o l} / \mathbf{k g})$ & 0.15 \\
Exchangeable $\mathbf{C a}(\mathbf{c m o l} / \mathbf{k g})$ & 2.46 \\
Exchangeable $\mathbf{M g}(\mathbf{c m o l} / \mathbf{k g})$ & 0.92 \\
\hline
\end{tabular}

Table 2: The chemical analysis of the organic compost used for the experiment.

\begin{tabular}{|c|c|c|c|c|c|c|c|c|c|c|}
\hline C & N & C/N & $\begin{array}{c}P \\
\end{array}$ & $\mathbf{K}$ & $\mathbf{N a}$ & $\mathrm{Ca}$ & Mg & $\mathbf{F e}$ & $\mathrm{Cu}$ & $\mathbf{Z n}$ \\
\hline$\%$ & $\%$ & ratio & $\mathrm{mg} / \mathrm{kg}$ & $\longleftarrow$ & & $\%$ & & & $\mathrm{mg} / \mathrm{kg}$ & - \\
\hline 26.7 & 4.13 & 6.46 & 382 & 1.21 & 1.02 & 0.32 & 0.43 & 36.47 & 0.14 & 1.42 \\
\hline
\end{tabular}


Table 3: Soil chemical properties at harvest in 2007.

\begin{tabular}{|c|c|c|c|c|c|c|c|c|c|}
\hline Treatment & pH & $\begin{array}{l}\text { Organic } \\
\text { matter } \\
(\mathrm{g} / \mathrm{kg})\end{array}$ & $\begin{array}{l}\mathbf{N} \\
(\mathrm{g} / \mathrm{kg})\end{array}$ & $\begin{array}{l}P \\
(\mathrm{mg} / \mathrm{kg})\end{array}$ & $\mathbf{K}$ & $\mathrm{Na}$ & $\begin{array}{l}\mathrm{Ca} \\
\mathrm{cmol} / \mathrm{kg}\end{array}$ & Mg & CEC \\
\hline $0 \mathrm{~kg} / \mathrm{ha}$ & 6.4 & 2.27 & 0.11 & 5.9 & 0.13 & 0.17 & 2.61 & 0.86 & 3.73 \\
\hline $\begin{array}{l}2 \mathrm{t} / \mathrm{ha} \\
\text { Organic } \\
\text { compost }\end{array}$ & 6.5 & 3.87 & 0.14 & 7.5 & 0.19 & 0.18 & 2.64 & 1.11 & 4.21 \\
\hline $\begin{array}{l}200 \mathrm{~kg} / \mathrm{ha} \\
\text { NPK 15- } \\
15-15\end{array}$ & 6.6 & 2.53 & 0.20 & 11.4 & 0.34 & 0.19 & 2.60 & 1.10 & 4.36 \\
\hline LSD (0.05) & NS & 0.43 & 0.04 & 1.2 & 0.02 & 0.02 & NS & 0.20 & 0.08 \\
\hline
\end{tabular}

Table 4: Soil chemical properties at harvest in 2008.

\begin{tabular}{|c|c|c|c|c|c|c|c|c|c|}
\hline Treatment & pH & $\begin{array}{c}\text { Organic } \\
\text { matter } \\
(\mathrm{g} / \mathrm{kg})\end{array}$ & $\begin{array}{c}N \\
(\mathrm{~g} / \mathrm{kg})\end{array}$ & $\begin{array}{c}P \\
(\mathrm{mg} / \mathrm{kg})\end{array}$ & $\mathbf{K}$ & $\mathbf{N a}$ & $\begin{array}{c}\mathrm{Ca} \\
\mathrm{cmol} / \mathrm{kg}\end{array}$ & Mg & CEC \\
\hline $0 \mathrm{~kg} / \mathrm{ha}$ & 6.3 & 2.17 & 0.14 & 7.9 & 0.19 & 0.16 & 2.44 & 0.93 & 3.81 \\
\hline $\begin{array}{l}2 \mathrm{t} / \mathrm{ha} \\
\text { Organic } \\
\text { compost }\end{array}$ & 6.2 & 4.77 & 0.28 & 11.6 & 0.40 & 0.16 & 3.19 & 2.54 & 6.46 \\
\hline $\begin{array}{l}200 \mathrm{~kg} / \mathrm{ha} \\
\mathrm{NPK} 15-15- \\
15\end{array}$ & 6.3 & 2.59 & 0.18 & 12.1 & 0.31 & 12.1 & 2.71 & 0.85 & 4.03 \\
\hline LSD (0.05) & NS & 0.18 & 0.04 & 1.1 & 0.04 & NS & 0.23 & 0.64 & 0.16 \\
\hline
\end{tabular}

Table 5: Soil chemical properties at harvest in 2009.

\begin{tabular}{|c|c|c|c|c|c|c|c|c|c|}
\hline Treatment & pH & $\begin{array}{l}\text { Organic } \\
\text { matter } \\
(\mathrm{g} / \mathrm{kg})\end{array}$ & $\begin{array}{l}N \\
(\mathrm{~g} / \mathrm{kg})\end{array}$ & $\begin{array}{l}P \\
(\mathrm{mg} / \mathrm{kg})\end{array}$ & $K_{4}$ & $\mathbf{N a}$ & $\begin{array}{l}\text { Ca } \\
\text { cmol/kg }\end{array}$ & Mg & CEC \\
\hline $0 \mathrm{~kg} / \mathrm{ha}$ & 6.2 & 2.27 & 0.14 & 9.1 & 0.16 & 0.16 & 2.47 & 0.98 & 3.82 \\
\hline $\begin{array}{l}2 \mathrm{t} / \mathrm{ha} \\
\text { Organic } \\
\text { compost }\end{array}$ & 6.8 & 4.80 & 0.27 & 14.2 & 0.42 & 0.14 & 3.52 & 1.55 & 6.48 \\
\hline $\begin{array}{l}200 \mathrm{~kg} / \mathrm{ha} \\
\text { NPK 15-15- } \\
15\end{array}$ & 5.6 & 2.59 & 0.19 & 12.8 & 0.30 & 0.15 & 2.68 & 0.83 & 4.04 \\
\hline LSD (0.05) & 0.5 & & 0.05 & 0.6 & 0.07 & NS & 0.20 & 0.43 & 0.75 \\
\hline
\end{tabular}


Table 6: Effect of organic compost and NPK fertilizer on the yield and vitamin C content of amaranth in 2007, 2008 and 2009.

\begin{tabular}{lcccccc}
\hline Treatment & \multicolumn{2}{c}{$\mathbf{2 0 0 7}$} & \multicolumn{2}{c}{$\mathbf{2 0 0 8}$} & \multicolumn{2}{c}{$\mathbf{2 0 0 9}$} \\
\hline & $\begin{array}{l}\text { Yield } \\
(\mathbf{t} / \mathbf{h a})\end{array}$ & $\begin{array}{l}\text { Vitamin C } \\
(\mathbf{m g} / \mathbf{1 0 0 g})\end{array}$ & $\begin{array}{c}\text { Yield } \\
(\mathbf{t} / \mathbf{h a})\end{array}$ & $\begin{array}{c}\text { Vitamin C } \\
(\mathbf{m g} / \mathbf{1 0 0 g})\end{array}$ & $\begin{array}{l}\text { Yield } \\
(\mathbf{t} / \mathbf{h a})\end{array}$ & $\begin{array}{c}\text { Vitamin C } \\
(\mathbf{m g} / \mathbf{1 0 0 g}) \mathbf{~}\end{array}$ \\
\hline $\mathbf{0 ~ k g / h a}$ & 4.27 & 12.41 & 4.87 & 12.62 & 4.81 & 12.75 \\
\hline $\begin{array}{l}\mathbf{2} \text { t/ha Organic } \\
\text { compost }\end{array}$ & 6.77 & 25.45 & 10.27 & 36.75 & 10.62 & 38.29 \\
\hline $\mathbf{2 0 0} \mathbf{k g} / \mathbf{h a}$ & 8.33 & 34.50 & 8.43 & 34.61 & 8.48 & 35.82 \\
NPK 15-15-15 & & & & & & \\
\hline LSD $(\mathbf{0 . 0 5})$ & $\mathbf{0 . 8 1}$ & $\mathbf{0 . 7 2}$ & $\mathbf{0 . 8 3}$ & $\mathbf{0 . 1 2}$ & $\mathbf{0 . 5 1}$ & $\mathbf{2 . 5 6}$ \\
\hline
\end{tabular}

Table 7: The yearly changes in soil chemical properties, yield and vitamin $\mathrm{C}$ content of amaranth in plot treated with $2 \mathrm{t} / \mathrm{ha}$ organic compost.

\begin{tabular}{|c|c|c|c|c|c|c|c|c|c|}
\hline Year & $\begin{array}{c}\text { Organic } \\
\text { Matter } \\
(\%)\end{array}$ & $\begin{array}{c}\mathrm{N} \\
(\mathrm{g} / \mathrm{kg})\end{array}$ & $\begin{array}{c}\mathbf{P} \\
(\mathbf{m g} / \mathbf{k g})\end{array}$ & $\mathbf{K}$ & $\begin{array}{c}\mathrm{Ca} \\
\mathrm{cmol} / \mathrm{kg}\end{array}$ & $\mathbf{M g}$ & $\underset{\longrightarrow}{\mathrm{CEC}}$ & $\begin{array}{l}\text { Yield } \\
\text { (t/ha) }\end{array}$ & $\begin{array}{l}\text { Vitamin C } \\
(\mathrm{mg} / 100 \mathrm{~g})\end{array}$ \\
\hline 2007 & 3.87 & 0.14 & 7.5 & $\overline{0.19}$ & 2.64 & 1.11 & 4.21 & 6.77 & 25.45 \\
\hline 2008 & 4.77 & 0.28 & 11.6 & 0.40 & 3.19 & 2.54 & 6.46 & 10.27 & 36.75 \\
\hline 2009 & 4.80 & 0.27 & 14.2 & 0.42 & 3.52 & 1.55 & 6.48 & 10.62 & 38.29 \\
\hline
\end{tabular}

Table 8: The yearly changes in soil chemical properties, yield and vitamin $C$ content of amaranth in plot treated with $200 \mathrm{~kg} / \mathrm{ha}$ NPK 15-15-15.

\begin{tabular}{|c|c|c|c|c|c|c|c|c|c|}
\hline Year & $\begin{array}{c}\text { Organic } \\
\text { Matter } \\
(\%)\end{array}$ & $\begin{array}{c}\mathbf{N} \\
(\%)\end{array}$ & $\begin{array}{c}\mathbf{P} \\
(\mathrm{mg} / \mathrm{kg})\end{array}$ & $\mathbf{K}$ & $\begin{array}{c}\mathrm{Ca} \\
\mathrm{cmol} / \mathrm{kg}\end{array}$ & Mg & $\begin{array}{r}\mathrm{CEC} \\
\longrightarrow\end{array}$ & $\begin{array}{l}\text { Yield } \\
\text { (t/ha) }\end{array}$ & $\begin{array}{c}\text { Vitamin } \\
\text { C } \\
(\mathrm{mg} / 100 \mathrm{~g})\end{array}$ \\
\hline 2007 & 2.53 & 0.20 & 11.4 & 0.34 & 2.60 & 1.10 & 4.36 & 8.33 & 34.50 \\
\hline 2008 & 2.59 & 0.18 & 12.1 & 0.31 & 2.71 & 0.85 & 4.03 & 8.43 & 34.61 \\
\hline 2009 & 2.59 & 0.19 & 12.8 & 0.30 & 2.68 & 0.83 & 4.04 & 8.48 & 35.82 \\
\hline
\end{tabular}

\section{DISCUSSION}

The soil nutrient status of the experimental site before the commencement of trial was evaluated following the categorization employed in Kparmwang and Malgwi (1997) for nutrient level of tropical soils while the slightly acidic soil status was based on the discussion of Brady and Weil (1999) of slightly acidic soils to have a pH range of 6 to 6.5 . The low soil nutrient status of the experimental site could be attributed to the previous continuous cropping without manure application thereby justifying the site for the research.

The eleven weeks duration for the composting was long enough for a mature compost to be produced while the trace elements $\mathrm{Cu}$ and $\mathrm{Zn}$ of 0.14 and $1.42 \mathrm{mg} / \mathrm{kg}$ respectively were far below the sealing limit of 400 and $700 \mathrm{mg} / \mathrm{kg}$ for $\mathrm{Cu}$ and $\mathrm{Zn}$ respectively. The quality assessment of compost as stipulated in the Canadian Council 
of Ministers of the Environment (CCME) 2005 had been employed in evaluating the suitability of the compost for the trial while the safe use of compost in improving soil fertility had been evaluated on the four criteria of the content of foreign matter, pathogen, trace elements and the maturity of compost.

The cumulative effects of inorganic fertilizers in causing an increase in soil acidity, at the end of the third year 2009 corroborated previous research by Devaney (2010) and Mae-Wan Ho (2010) on the increase in soil acidity caused by long term use of chemical fertilizers, while the higher $\mathrm{pH}$ values observed in plot treated with organic compost agreed with previous findings of Whalen (2000) who experimented with the use of cattle manure amendments to increase the $\mathrm{pH}$ of acid soils.

The higher organic matter content in the plot treated with organic compost relative to other treatment plots agreed with previous observation of Esawy et al. (2009) on the increase in organic matter as a result of addition of rice straw compost while the yearly increase in organic matter content in the organic compost treated plot corroborated previous research on the cumulative effects of addition of organic manure to soils (Ali et al., 2009). The higher nitrogen, phosphorus, potassium and cation exchange capacity in plot treated with $200 \mathrm{~kg}$ NPK fertilizer over the organic compost plot in the first year 2007 could be attributed to the immediate availability of nutrients in the chemical fertilizer as previously observed by (Makinde et al., 2010), while the higher nutrient content in organic compost plot over the NPK plot in 2008 and 2009 could be as a result of nutrient slow release but with high residual pool of the nutrients ( Bedi and Dubey, 2009; Canellas et al., 2010).

The significantly higher amaranth yield of $8.33 \mathrm{t} /$ ha obtained in NPK plot compared to the organic compost plot in 2007 could be attributed to the immediate release and availability of nutrients while the higher residual nutrient build-up in the organic compost treated plot which reflected in the higher yield in 2008 and 2009 respectively could be due to the long-term nutrient releasing capability of the organic compost which corroborated previous research (Kolade et al., 2006). The vitamin $\mathrm{C}$ content which became significantly higher in the second year 2008 and the third year 2009 in the plot treated with organic compost agreed with previous report inferring increase in organic matter content to lead to an increase in soil microbial population (Chitravadivu et al., 2009; Nakhro and Dkhar, 2010) while a high microbial population had been reported to improve the antioxidant capability of the soil which according to Skwarylo-Bednarz and Krzepilko (2008) could lead to an increasing vitamin $\mathrm{C}$ content in amaranth. The yearly increase in soil nutrient, yield and vitamin $\mathrm{C}$ content of amaranth was as a result of the organic compost contributing to the residual pool of nutrients in the soil which released the nutrients slowly thereby preventing quick leaching or loss of nutrients (Van den Bosch et al., 1998; Makinde et al., 2010).

\section{Conclusion}

The immediate availability of nutrients in the NPK 15-15-15 plot resulted in higher content of nitrogen, phosphorus and potassium which reflected in the higher yield and vitamin $\mathrm{C}$ content of amaranth compared to the compost treated plot in the first year 2007. However, the higher residual pool and the gradual release of nutrients in the organic compost treated plot resulted in higher nutrient status which reflected in the sustained high yield and vitamin $\mathrm{C}$ content of amaranth than in the NPK treated plot in the second and third 2008 and 2009 production years respectively. The application of organic compost ensured a sustained soil productivity and amaranth production and quality than the NPK fertilizers.

\section{REFERENCES}

Akingbade JO, Adeyemi IA, Sangodoyin SO Oke OL. 1994. Evaluation of 
amaranth grains for ogi manufacture. Plant Foods for Human Nutrition, 46(1): $19-26$.

Ali MA, Molla MSH, Alam MR Mornin MA Mannan MA. 2009. Effect of combinations of chemical fertilizers and poultry manure on the productivity of crops in the cauliflower-stem amaranthjute. Bangladesh Journal of Agricultural Research, 34(1): 113 - 121.

AOAC (Association of Official Analytical Chemists) 1970. Official Methods of Analysis $\left(12^{\text {th }}\right.$ edn). AOAC: Arlington, VA.

Bedi P, Dubey YP. 2009. Long-term influence of organic and inorganic fertilizers on nutrient build-up and their relationship with microbial properties under a rice-wheat cropping sequence in an acid alfisol. Acta Agronomica Hungarica, 57: 297-306.

Bodroza-Solarov M, Filipcev B, Kevresan Z, Mandic A, Simurina O. 2008. Quality of bread supplemented with popped Amaranthus cruentus grain. Journal of Food Process Engineering, 31: 602 618.

Brady NC, Weil RR. 1999. The Nature and Properties of Soils. $\left(12^{\text {th }}\right.$ edn). Prentice Hall: New Jersey; 881p.

Bressani R, De Martell ECM, De Godinez CM. 1993. Protein quality evaluation of amaranth in adult humans. Plant Foods for Human Nutrition, 43(2): 123 - 143.

Canadian Council of Ministers of the Environment (CCME), 2005. Guidelines for Compost Quality. http://www.ccme. ca/assets/pdf/compostgdlns_1340_e.pdf

Canellas LP, Busato JG, Dobbss LB, Baldotto MA, Rumjanek VM, Olivares FC. 2010. Soil organic matter and nutrient pools under long-term non-burning management of sugarcane. European Journal of Soil Science, 61(3): 375-383.

Carter MR. 1993. Soil Sampling and Methods of Soil Analysis. Canadian Society of Soil Science. Lewis Publishers: London; 823p.
Chitravadivu C, alakrishnan V, Manikandan J, Elavazhagan T, Jayakumar S. 2009. Application of food waste compost on soil microbial population. Middle East Journal of Scientific Research, 4(2): 9093.

Condes MC, Scilingo AA, Anon MC. 2009. Characterization of amaranth proteins modified by trypsin proteolysis Structural and functional changes. Food Science and Technology, 42(5): 963-970.

De-Lannoy G. 2001. Leaf Vegetables. Raemaekers RH (ed). Goekint Graphics nv: Belgium; 1540p.

Devaney E. 2010. Environmental Effects of Chemical Fertilizers. http://www.ehow. com/facts_envt-effects fert.html

Esawy M, Mahmoud I, Paul R, Nouraya A, Mohamme E. 2009. Rice Straw Composting and its Effect on Soil Properties.http://findarticles.com/p/article s/mi_7510/is_200907/ai_n39231352

Kolade OO, Coker AO, Sridhar MKC and Adeoye GO. 2006. Palm kernel waste management through composting and crop production. Journal of Environmental Health Research, 5(2): 8185.

Kparmwang T, Malgwi WB. 1997. The Genesis, Classification and Productivity Limitations of Sandstone soils in Northwestern Nigeria. Proceedings of the $23^{\text {rd }}$ Annual Conference of Soil Science Society of Nigeria, Singh BR (ed.), pp.4350.

Madeleine I, de Smet P, Tersmette $T$, Veldkamp T. 2002. Preparation and use of compost. The Technical Centre for Agriculture and Rural Cooperation (CTA), Agrodok series No. 8, 68p.

Mae-Wan Ho, 2010. China's Soils Ruined by Overuse of Chemical Fertilizers. http://www.isis.org.uk/chinasSoilRuined.p hp.

Makinde EA, Fagbola O, Akinrinde EA, Makinde, EA. 2010. Effects of organic, organomineral and NPK fertilizer treatment on the quality of Amaranthus 
cruentus (L.) on two soil types in Lagos, Nigeria. Nature and Science, 8(3): 56-62.

Nakhro N, Dkhar MS. 2010. Impact of organic and inorganic fertilizers on microbial populations and biomass carbon in paddy field soil. Journal of Agronomy, 9: $102-110$.

Ogunlesi M, Okiei W, Azeez L, Obakachi V, Osunsanmi M, Nkenchor G. 2010. Vitamin C contents of Tropical Vegetables and Foods Determined by Voltametric and Titrimetric methods and their relevance to the medicinal uses of the plants. International Journal of Electrochemical Science, 5: 105-115.

Ramesh P, Panwar NR, Singh AB, Ramana S, Rao AS. 2009. Impact of organic manure combinations on the productivity and soil quality in different cropping systems in central India. Journal of Plant Nutrition and Soil Science, 172(4): 577585.

Selma MV, Ascensi MS, Allende A, Ros M, Hernndez MT Gil M. 2010. Impact of Organic Soil Amendments on Phytochemicals and Microbial Quality of Rocket Leaves (Eruca sativa). Journal of
Agricultural Food and Chemistry, 58(14): 8331-8337.

Skwarylo-Bednarz B, Krzepilko 2009. Effect of various NPK fertilizer doses on total antioxidant capacity of soil and amaranth leaves (Amaranthus cruetus L.). International Agrophysics, 23: 61-65.

Smyth AJ, Montgomery RF. 1962. Soils and Land use in Central Western Nigeria. Government Printer: Ibadan, Western Nigeria; 265p.

Tironi VA Anon MC. 2010. Amaranth proteins as a source of antioxidant peptides: Effect of proteolysis. Food Research International, 43(1): 315-322.

Van den Bosch H, Gitari JN, Ogaro VN, Maobe S, Vlaming J. 1998. Monitoring nutrient flows and economic performance in African farming systems (NUTMON). III. Monitoring nutrient flows and balances in three districts in Kenya. Agriculture, Ecosystems and Environment, 71: 63-80.

Whalen JK, Chang C, Clayton GW, Carefoot JP. 2000. Cattle manure amendments can increase the pH of acid soils. Soil Science of American Journal, 64: 962-966. 